\title{
NILAI KARAKTER DALAM FOKLORE DORE DI JORONG KUBU TUNTUANGAN, KABUPATEN TANAH DATAR, SUMATERA BARAT
}

\author{
Dian Permata Sari ${ }^{1 *}$, Benni Andika ${ }^{2 *}$ \\ Program Studi Seni Teater Jurusan Seni Pertunjukan \\ Institut Seni Budaya Indonesia (ISBI) Aceh \\ Jl. Transmigrasi, Gampong Bukit Meusara, Kec. Kota Jantho, Kab. Aceh Besar, 23911 \\ Aceh. Indonesia \\ Email: dianpermatasari@isbiaceh.ac.id,benniandika@isbiaceh.ac.id
}

\begin{abstract}
Abstrak
Penelitian ini bertujuan untuk menjelaskan tentang nilai karakter dalam Foklore Dore di Jorong Kubu Tuntuangan Kenagarian Batipuah Kecamatan Batipuah Baruah Kabupaten Tanah Datar provinsi Sumatera Barat dengan pendekatan Folklore. Dalam hal ini metode yang digunakan adalah deskriptif kualitatif. Data penelitian ini berupa perkataan, perbuatan, tingkah laku dan aktivitas yang dilakukan dalam Foklore Dore di Jorong Kubu Tuntuangan Kenagarian Batipuah Kecamatan Batipuah Baruah Kabupaten Tanah Datar sebagai salah satu bentuk permainan rakyat yang terdapat di Minangkabau. Instrumen penelitian ini adalah peneliti sebagai instrumen kunci. Dengan demikian, folklore non lisan tersebut dapat dijadikan rujukan untuk membentuk pendidikan karakter anak.
\end{abstract}

Kata Kunci: foklore dore, nilai karakter.

Abstract

This study aims to explain the character values in Foklore Dore in Jorong Kubu Tuntuangan Kanagarian Batipuah, Batipuah Baruah, Tanah Datar, West Sumatra using the Foklore approach. In this case the method used is descriptive qualitative. The data of this research are in the form of words, actions, behavior and activities carried out in the Foklore Dore in Jorong Kubu Tuntuangan Kanagarian Batipuah, Batipuah Baruah, Tanah Datar as a form of folk games found in Minangkabau. The research instrument was the researcher as a key instrument. Thus, the non-verbal Foklore can be used as a reference for shaping children's character education.

Keywords: foklore dore, character value.

\section{PENDAHULUAN}

Aktivitas kehidupan masyarakat tidak terlepas dari aktivitas bersastra. Sastra sebagai suatu bentuk seni kreativitas manusia yang senantiasa lahir dari rutinitas kehidupan masyarakat, memberi pengaruh dan dampak positif tehadap perkembangan hidup manusia. Sastra juga berkembang sesuai dengan ritme kehidupan masyarakat. Sastra sebagai bentuk kreativitas manusia juga berlaku di setiap lapisan masyarakat. Mulai dari yang berbentuk lisan ataupun tulisan sastra merupakan bagian dari pelilaku kehidupan masyarakatnya. Salah satu bentuk sastra yang melekat dalam kehidupan keseharian manusia dalah Foklore Dore .

Foklore Dore dapat diartikan sebagai kebudayaan yang diwariskan secara turun-temurun. Berbagai jenis aktivitas bersastra dalam bentuk Foklore Dore yang terdapat di masyarakat sangat beraneka ragam. Ada berupa Foklore Dore lisan, Foklore Dore bukan lisan, dan Foklore Dore sebagaian lisan. Penelitian ini menjandi penting dilakukan, dikarenakan saat ini untuk membentuk karakter anak-anak bukan hanya di mulai dari pendidikan sekolah dasar, namun juga bias di terapkan lewat ragam permainan yang berkembang di masyarakat.

Permainan rakyat merupakan Foklore Dore yang berbentuk sebagian lisan. Biasanya dilakukan masyarakat untuk mengisi waktu senggang. Sesuai dengan perubahan peradaban manusia dan berkembangnya ilmu pengetahuan, informasi dan teknologi, permainan rakyat tereduksi permainan modern yang lebih menarik. Permainan rakyat menjadi kurang diminati. Akibatnya banyak permainan rakyat, yang tidak dikenalatau memang tidak diperkenalkan kepada anakanak, sehingga anak-anak mulai tidak mengenal jenis-jenis permainan rakyat yang ada di masyarakat. 
Di Minangkabau, permainan rakyat juga beraneka ragam. Meskipun ada bentuk permainan yang sama tetapi di beberapa daerah memiliki nama yang berbedabeda di setiap daerah. Ada beberapa permainan rakyat yang sangat menonjol di masyarakat Minangkabau yaitu, main dore, main sepak tekong, main galah, main gasiang, main tali, main banda.

Foklore Dore tidak hanya sebagai salah satu bentuk permainan rakyat yang masih dimainkan secara turuntemurun. Namun di dalam Foklore Dore juga terdapat berbagai nilai karakter yang dapat bersifat positif yang dapat di gali, agar permainan rakyat tetap bisa dikenal oleh masyarakat sebagai salah satu bentuk permainan tradisional yang harus tetap dilestarikan.

Berdasarkan hal tersebut maka untuk kepentingan penelitian ini ditetapkan topik nilai karakter dalam Foklore Dore. Setting penelitian dilakukan di Jorong Kubu Tantungan Kanagarian Batipuah Kecamatan Batipuah Baruah Kabupaten Tanah Datar. Alasan utama menetapkan nilai karakter dalam Foklore Dore karena permainan ini sudah hampir punah di masyarakat. Padahal dalam Foklore Dore selain untuk menghibur, juga sarana untuk menanamkan nilai-nilai karakter yang diinginkan orang tua terhadap anaknya. Nilai tersebut diperoleh melalui proises permainan itu yang dilakukan berulang-ulang.

Berdasarkan latar belakang masalah tersebut, maka fokus masalah pada penelitian ini adalah nilai karakter yang terdapat dalam Foklore Dore di Jorong Kubu Tantungan Kenagarian Batipuah Kabupaten Tanah Datar. Tujuan penelitian ini adalah untuk mendeskripsikan nilai karakter yang terdapat dalam Foklore Dore Dore di Jorong Kubu Tuntuangan Kenagarian Batipuah Kecamatan Batipuah Baruah Kabupaten Tanah Datar.

\section{KAJIAN TEORI}

Secara etimologi kata "foklor" adalah pengindonesiaan katabahasa Inggris folklore. Kata ini adalah kata majemuk, yang berasal dari dua kata dasar folk dan dore. Folk adalah sekelompok orang yang memiliki ciri-ciri pengenal fisik, sosial, dan budaya sehingga dapat dibedakan dari kelompok-kelompok lainnya. Ciri-ciri pengenal itu antara lain dapat berwujud warna kulit, bentuk rambut yang sama, mata pencaharian yang sama, bahasa yang sama, taraf pendidikan yang sama, dan agama atau kepercayaan yang sama. Namun, yang lebih penting lagi adalah bahwa mereka telah memiliki suatu tradisi, yakni kebiasaan yang telah mereka warisi turun temurun, sedikitnya dua generasi,yang dapat mereka akui sebagai milik bersama mereka. Di samping itu, mereka sadar akan identitas kelompok mereka sendiri Jadi folk adalah sinonim dengan kolektif, yang juga memiliki ciri-ciri pengenal fisik atau kebudayaan yang sama serta mempunyai kesadaran kepribadian sebagai kesatuan masyarakat.

Dore adalah kebiasaan sedangkan folk, yaitu sebagian kebudayaannya, yang diwariskan secara turuntemurun secara lisan atau melalui suatu contoh yang disertai gerak isyarat atau alat pembantu pengingat. Dari uraian diatas dapat didefinisikan bahwa folklore adalah sebagian kebudayaan suatu kolektif, yang tersebar dan diwariskan secara turun-temurun, di antara kolektif macam apa saja, secara tradisional dalam versi yang berbeda, baik dalam bentuk lisan maupun contoh yang disertai dengan gerak isyarat atau alat pembantu pengingat. Berkenaan dengan jenis kebudayaannya, Suwardi (2009: 20) menyatakan bahwa folklor adalah bagian dari kebudayaan yang bersifat tradisional, tidak resmi, dan nasional. Pandangan ini menyiratkan bahwa folklor bukan hanya yang bersifat etnik, melainkan juga yang nasional; yang penyampainnya secara tidak resmi.

\section{Folklor Sebagai Media Pendidikan}

Pendidikan adalah seluruh usaha mengembangkan pengetahuan, keterampilan, dan karakter yang baik warga masyarakat terutama generasi muda. Pendidikan merupakan usaha sadar dan sistematis yang bertujuan untuk memanusiakan manusia dengan memberikan pengetahuan dan keterampilan sehingga akan tercipta manusia seutuhnya. Pendidikan berkenaan dengan segala kegiatan yang berguna untuk menambah pengetahuan baik itu pengetahuan seseorang maupun pengetahuan sekelompok orang. Pengetahuan tersebutmemerlukan media sebagai perantara penyampaiannya, yang disebut dengan media pendidikanagar sampai kepada masyarakat. Kata media berasal dari bahasa Latin medius yang secara harfiah berarti 'penengah', 'perantara', 'sarana' atau 'pengantar'. Perantara, sarana, penengah atau pengantar itu mungkin berupa benda, peristiwa atau manusia.

Artinya, media merupakan segala sesuatu yang dapat digunakan untuk menyalurkan pesan, mengasah pikiran, merangsang perasaan, menarik perhatian, dan membangkitkan kemauan sesorang sehingga terlibat dalam sebuah proses kegiatan.Media adalah alat,cara, perantara atau saranayang digunakan untuk menyampaikan informasi, sedangkan pendidikan dapat diartikan sebagai suatu proses pembelajaran dan pemberian pengetahuan, keterampilan,dan karakter melalui pendidik atau pengajar kepada muriddengan menggunakan pranata-pranata agar tujuan yang ingin 
dicapai dapat dipenuhi. Pranata-pranata yang dimaksudkan dapat bersifat formal, nonformal atau informal. Dalam hal ini keluarga dan sekolah merupakan pranata yang paling utama dalam melaksanakan pendidikan seorang individu.

Media pendidikan dapat diartikan sebagai alat atau carayang digunakan oleh pengajar untuk menyampaikan pelajaran kepada siswanya dalam proses pembelajaran. Media yang digunakan oleh pendidik atau pengajar dalam proses belajar mengajar sangat beraneka ragam tergantung apa yang diajarkannya. Media berfungsi untuk mempermudah, mengefektifkan, bahkan mengefisienkan penyampaian informasi dalam proses belajar mengajar.Pemilihan media dalam proses mengajar juga harus dicocokkan dengan materi yang diajarkan. Media sebagai alat bisa berupa gambar, infocus, atau alat peraga lain, sedangkan media sebagai cara bisa berupa metode atau strategi untuk menyampaikan pelajaran.

Media pendidikan adalah seluruh alat, cara atau perantara yang digunakan oleh seorang tenaga pendidik (guru) untuk menyampaikan informasi yang berguna dalam pengembangan pengetahuan peserta didik (murid). Menurut Arsyad (dalam B.F.Skinner, media pendidikan berfungsi untuk membuat (1) penyampaian pesan pembelajaran dapat lebih terstandar, (2) pembelajaran dapat lebih menarik, (3)pembelajaran menjadi lebih interaktif dengan menerapkan teori belajar, (4) waktu pelaksanaan pembelajaran dapat diperpendek, (5) kualitas pembelajaran dapat ditingkatkan, (6) proses pembelajaran dapat berlangsung kapanpun dan di manapun diperlukan, (7) sikap positif siswa terhadap materi pembelajaran serta proses pembelajaran dapat ditingkatkan, (8) peran guru berubah kearah yang positif. Pentingnya media pendidikan dalam proses pendidikan dijelaskan pada teori tingkah laku belajar .

Menurut Darmodiharjo (dalam Setiadi, 2006: 117) mengungkapkan "Nilai merupakan sesuatu yang berguna bagi manusia baik jasmani maupun rohani". Nilai dapat memberi manfaat dan makna baik jasmani maupun rohani pada hidup seseorang. Sehingga nilai yang tertanam dalam rohani seseorang akan tergambar pada kegiatan atau aktivitas jasmaninya. Nilai adalah memberi makna pada hidup, memberi acuan, titik tolak dan tujuan hidup. Nilai juga dijadikan standar untuk melakukan suatu tindakan atau perbuatan dalam kehidupan sehari-hari. Linda dan Eyre (dalam Adisusilo, 2012: 57) "nilai adalah standar-satandar perbuatan dan sikap yang menentukan siapa kita, bagaimana kita hidup, dan bagaimana kita memperlakukan orang lain". Berdasarkan teori diatas dapat disimpulkan bahwa nilai adalah perbuatan atau tindakan yang dilakukan berdasarkan nilai yang baik akan mempengaruhi sikap seseorang dalam memperlakukan orang lain secara lebih baik dalam pergaulan di masyarakat.

Nurachman (dalam Soedarsono, 2008:16) mengemukakan karakter adalah sistem daya juang yang menggunakan nilai-nilai moral yang tertanam dalam diri kita yang melandasi pemikiran, sikap dan perilaku. Karakter juga berfungsi untuk mentransformasikan tata nilai dan pembentukan karakter seseorang.

Mulyana (dalam Damayanti, 2010: 7) menyebutkan Ada lima sikap dasar nilai karakter yaitu (1) jujur, (2) terbuka, (3) berani mengambil resiko dan bertanggung jawab, (4) komitmen, dan (5) berbagi. Disamping itu ada nilai lain yang menjadi tolak ukur yang menunjang kecerdasan seseorang. Prayitno dan Afriva Khaidir (2011: 130-139) mengungkapkan bahwa kecerdasan adalah kemampuan berpikir logis dan terbuka serta mampu memecahkan masalah dan menemukan solusi atas berbagai persoalan. Kecerdasan berpikir dapat menciptakan masyarakat yang cerdas dalam menjalani kehidupan sehari-hari. Mulyana (dalam Damaianti, 2010: 7) mengemukakan bahwa kepedulian adalah seseorang yang mampu berbagi apa yang dimilikinya, baik bersifat benda atau pengetahuan kepada orang lain. Apabila seseorang menjadi pemimpin maka selain peduli pada diri sendiri juga harus peduli pada orang di sekelilingnya. Dengan rasa kepedulian ini akan meningkatkan rasa kebersamaan.

Prayitno dan Afriva Khaidir (2012: 130-139) menyatakan bahwa "Kepedulian merupakan keadaan seseorang untuk patuh, loyal, sopan santun, suka menolong terhadap sesame serta damai dan pemaaf'. Kepedulian tidak hanya pada diri sendiri tetapi terhadap pemerintahan dan hokum yang berlaku. Berdasarkan pendapat ahli tersebut, dapat disimpulkan bahwa kepedulian merupakan suatu sikap yang menuntut seseorang untuk mampu berbagi kepada orang lain baik materi maupun nonmateri, serta mendorong seseorang untuk selalu peduli kepada keadaan di sekitarnya baik lingkungan maupun pemerintaha. Untuk kepentingan penelitian ini untuk mendeskripsikan.

\section{Teori Nilai Prayitno dan Afriva Khaidir (2011:130-139) untuk Melihat Nilai Karakter Foklore Dore}

Jorong Kubu Tantungan Kenagarian Batipuah Kecamatan Batipuah Baruah Kabupaten 


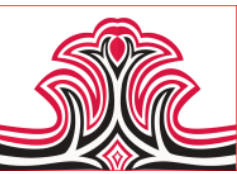

Tanah Datar memiliki tiga jenis nama Foklore Dore yaitu (a) foklor dore rok, (b) Foklore Doredore baju (c) Foklore Dore petak. Ketiga jenis nama tersebut hanya merupakan variasi sebutan pada kelompok bermain tertentu. Foklore Dore ini biasanya hanya dilakukan oleh anak-anak perempuan. Petak dalam Foklore Dore berbentuk gabungan beberapa segi empat dan segitiga yang berjumlah delapan kotak. Untuk kepentingan penelitian ini istilah yang akan dipakai terhadap analisis permaiann dore yang dimaksud adalah dore rok.

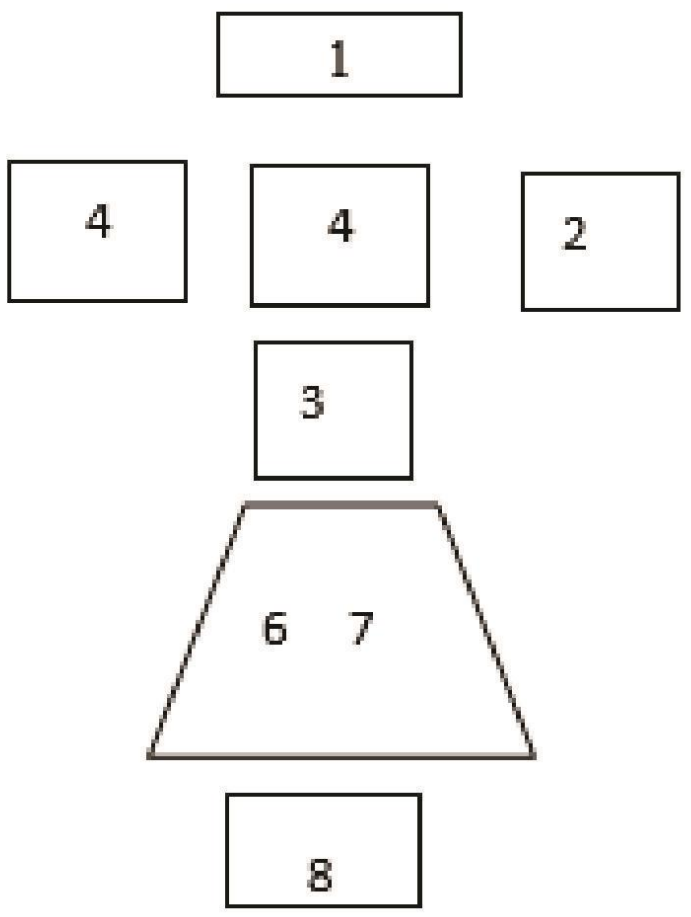

Gambar 1. Denah Foklore Dore Rok (Sari, 2020)

Sebelum melakukan Foklore Dore Rok, ada beberapa langkah pemainan yang harus dilalui. Langkah Foklore Dore rok akan dijabarkan sebagai berikut: Tahap kegiatan pertama pada Foklore Dore rok yaitu tahap persiapan dan memulai permainan. Dalam tahap persiapan membuat lucak. Lucak digunakan sebagai anak dore untuk menntukan gilir dan tempat melangkah selanjutnya dalam petak-petak dore. Lucak dibuat dari pecahan keramik atau pecahan piring. Yang ditumpulakn sisi-sisinya dengan cara menggosokkannya ke batu. Bentuk lucak yang digunakan tidak konsisten, dalam arti bebas sesuai keinginan dan kenyamanan pemain menggunakannya.

Setiap pemain memiliki satu lucak. Langkah berikutnya membuat petak dore rok di atas tanah atau lapangan. Setelah dore dibuat ditentukan siapa yang akan memulai permainan pertama kali, berdo'a
Gorga : Jurnal Seni Rupa

Volume 10 Nomor 01 Januari-Juni 2021

p-ISSN: 2301-5942 | e-ISSN: 2580-2380

sebelum melakukan kegiatan permainan. Tiap-tiap kegiatan tersebutakan dijabarkan sebagai berikut: Kegiatan kedua adalah membuat petak dore rok di atas tanah atau lapangan. Petak dore rok terbentuk dari gabungan segi empat dan segitiga. Pertama kali pemain akan membuat tiga buah segi empat dengan menyusunnya seperti anak tangga ( petak 1,2 dan 3). Kedua membuat segi empat (petak nomor 4 dan 5) untuk lengan kiri dan kanan. Ketiga membuat segi empat yang berbentuk trapesiun sehingga memberi kesan bentuk rok tapi diberi garis tengah yang berguna sebagai pembatas loncatan (6 dan 7). Keempat membuat petak segi empat yang memberi kesan kaki.(8).

Kegiatan ketiga adalah menentukan siapa yang akan memulai permainan pertama kali. Untuk menentukan pemain pertama para pemain melakukan suit (balasik). Cara melaksanakan suit (balasuik) ada suit jari atau suit tangan. Suit jari dilakukan dengan menghitung jumlah jari menang yang diperoleh antara jari telunjuk, kelingking dan jempol. Jika keluar jari jempol dan kelingking maka, yang menang adalah jari kelingking. Jika yang keluar jari jempol dan telunjuk maka, yang menang adalah jempol. Jika yang keluar jari telunjuk dan kelingking maka, yang menang adalah jari telunjuk. Tetapi jika yang keluar adalah jari yang sama maka tidak ada nilainya. Sedangkan suit tangan adalah suit yang dilakukan dengan menghitung jumlah yang muncul antara telapak tangan dan punggung tangan. Dalam melaksanakan suit ini para pemain menyebutkan kata banyak atau saketek. Kegiatan keempat adalah tahap bermain.

Tahap bermain pertama kali adalah melemparkan lucak pada petak dore nomor satu. Lalu, menggeser lucak tersebut kepetak nomor dua dengan posisi berdiri dengan satu kaki sampai petak nomor lima. Ketika berada di petak nomor lima kita berdiri dengan dua kaki. Selanjutnya, meloncak kembali ke petak nomor enam sambil menggeser lucak sampai habis petak dore dengan posisi kaki satu. Setelah semua petak dore dilalui maka lucak yang sudah sampai garis finis haris di injak dengan kaki. Begitu selanjutnya sampai petak nomor delapan. Ketiga, tahap mencari bintang. Di mana pemain berdiri digaris star dengan membelakangi petak dore. Lucak yang dipegang dipindahkan letaknya ke punggung tangan dengan cara disimbang.Setelah itu dilemparkan ke belakang melalui atas kepala. Lemparan diusahakan dengan perkiraan menempati petak dore. Jika lemparan lucak tepat jatuh pada petak dore, maka itu yang menjadi bintang. Jadi pemain pertama yang mendapat bintang itulah yang menjadi pemenang. 


\section{METODE PENELITIAN}

\section{Tahap Kerja Lapangan}

Langkah selanjutnya adalah tahap kerja lapangan untuk mengumpulan data yang akan dianalisis menjadi sebuah bentuk laporan. Dengan melakukan studi lapangan yaitu pengumpulan data-data dengan cara melakukan observasi, wawancara serta pendokumentasian yang mengunakan alat dokumentasi seperti kamera foto, kamera vidio dan alat perekam berupa handphone. Dalam tahap kerja lapangan atau diistilahkan dengan studi lapangan ini ditempuh melalui beberapa tahap-tahap sebagai berikut:

\section{1). Observasi}

Terkait dengan pentingnya langkah observasi (pengamatan) dalam setiap penelitian. Penulis dalam hal ini akan mengamati secara langsung aktivitas pra hingga pasca pertunjukan folklore dore. Gunanya sebagai pendukung terhadap data yang diperoleh dalam studi pustaka pada tahap pra lapangan, sekaligus untuk meminimalisir keraguan agar tidak terjadinya bias data yang diperoleh sebelum penelitian lewat studi pustaka yang dilakukan.

\section{2). Wawancara}

Proses dalam tahap ini (wawancara) akan dilakukan dalam bentuk tanya jawab antara penulis dan informan yang berkaitan langsung dengan objek yang diteliti. Narasumber yang penulis temui adalah pelaku foklore dore diantara tetua adat kubu tantungga, akademisi sastra lisan, murid-murid Sekolaj Dasar dan Sekolah Menengah Pertama yang sedang berlatih folklore dore dengan tujuan agar penulis mendapatkan data-data yang akurat tentang objek penelitian ini nantinya.

\section{3). Pendokumentasian}

Proses pendokumentasi sangat penting gunanya untuk membantu melengkapi data-data sebagai penunjang suatu penelitian dalam tahapan lanjutan analisis dan pengolahan data yang didapat di lapangan nantinya. Proses pendokumentasian mengunakan instrumen penelitian. Tahapan ini dilakukan dengan memanfaatkan kamera foto, kamera vidio, dan alat perekam audio berupa handphone.

\section{4). Analisis dan Penyusunan Laporan}

Setelah mendapatkan data-data tentang objek yang akan diteliti melalui narasumber yang telah ditemui selama proses penelitian nilai karaakter folklore dore di jorong Kubu Tuntuangan, Kabupaten Tanah Datar, Sumatera Barat berlangsung, maupun dari sumbersumber lain seperti dari jurnal, laporan penelitian, buku, dan Skripsi. Selanjutnya data-data tersebut akan dipilih dan dilakukan penyisihan untuk kemudian dianalisis. Data-data yang dianalisis kemudian disusun menjadi sebuah laporan penelitian.

Jenis Penelitian yang digunakan adalah penelitian kualitatif dengan metode deskriptif. Richie (dalam moleong, 2009: 6) menyatakan "Penelitian kualitatif adalah upaya menyajikan dunia dan perspektifnya di dalam dunia dari segi konsep, prilaku, persepsi dan persoalan tentang manusia yang di teliti". Penyajian data dalam penelitian kualitatif juga berbeda dengan penelitian kuantitatif. Arikunto (2006: 12) menjelaskan bahwa "Penelitian kualitatif biasa dilawankan dengan penelitian kuantitatif dengan alasan bahwa dalam kegiatan penelitian ini peneliti tidak menggunakan angka dalam mengumpulkan data dan dalam memberikan penafsiran terhadap hasilnya".

Selanjutnya, Nazir (2003: 54) mengungkapkan bahwa "Metode deskriptif adalah suatu metode dalam meneliti suatu kelompok manusia, suatu objek, suatu set kondisi, suatu sistem pemikiran ataupun suatu kelas peristiwa pada masa sekarang”. Jadi data yang diperoleh dideskripsikan untuk menggambarkan data secara jelas dan rinci, selanjutnya dianalisis dan dibahas untuk menjawab masalah. Data dalam penelitian ini berupa perkataan, perbuatan dan tingkah laku dan aktivitas yang dilakukan dalam Foklore Dore di Jorong Kubu Tantungga Kenagarian Batipuah Kecamatan Batipuah Baruah Kabupaten Tanah Datar sebagai salah satu bentuk permainan rakyat yang terdapat di Sumatera Barat.

Sumber data terdiri atas sumber data lisan dan tulisan. Sumber data lisan diperoleh melalui observasi saat mengamati langsung Foklore Dore di Jorong Kubu Tantungga Kenagarian Batipuh Baruah dan wawancara dengan informan . Sedangkan sumber tulisan berupa hasil transkripsi dari data lisan informan yang dilakukan peneliti saat melakukan wawancara Foklore Dore di Kenagarian Batipuah Kecamatan Batipuh Baruah Kabupaten Tanah Datar. Informan utama pada penelitian ini adalah ibu Meri Ketua PKK Jorong Kubu Tantungga Kenagarian Batipuah Baruah Kabupaten Tanah Datar, kedua adalah ibu Nuraini, dan ketiga adalah ibu Syukria Liberti.

Instrumen dalam penelitian ini adalah peneliti sebagai instrumen kunci. Untuk mengumpulkan data, peneliti mengamati secara langsung kegiatan Foklore Dore di Kenagarian Batipuah Kecamatan Batipuh Baruah Kabupaten Tanah Datar dengan menggunakan alat bantu berupa Kamera. Hal ini sesuai dengan pendapat Moleong (2009: 121) bahwa yang menjadikan instrumen dalam penelitian kualitatif adalah peneliti itu 
sendiri dibantu dengan alat yang dibutuhkan. Moleong (2009: 225) berpendapat bahwa teknik pengumpulan data yang digunakan dalam penelitian ini adalah peneliti mengobservasi langsung kegiatan Foklore Dore di Jorong Kubu Tantungga Kenagarian Batipuah Kecamatan Batipuh Baruah Kabupaten Tanah Datar. Untuk mendapatkan informasi terkait dengan kepentingan penelitian, peneliti juga melakukan pengumpulan data melalui pengambilan foto kegiatan Foklore Dore di Jorong Kubu Tantungga Kenagarian Batipuah Kecamatan Batipuh Baruah Kabupaten Tanah Datar.

Objek dan masalah penelitian memang mampengaruhi pertimbanganpertimbangan mengenai pendekatan, desain, ataupun metode penelitian yang akan diterapkan. Tidak semua objek dan masalah penelitian bisa didekati dengan pendekatan tunggal, sehingga diperlukan pemahaman pendekatan lain yang berbeda dengan tujuan objek dan masalah yang akan diteliti, tidak pas atau kurang sempurna dengan satu pendekatan. Maka pendekatan lain dapat digunakan, atau bahkan mungkin menggabungkannya. Tujuan rancangan penelitian adalah melalui penggunaan metode penelitian yang tepat, dirancang kegiatan yang dapat memberikan jawaban yang diteliti terhadap pertanyaan-pertanyaan penelitian.

Metode berfungsi untuk menyederhanakan masalah, sehingga lebih mudah untuk dipecahkan dan dipahami. Pernyataan tersebut dipertegas Iskandarwassid dan Sunendar (2009: 56) yang mengatakan bahwa metode lebih bersifat prosedural dan sistemik karena tujuannya untuk mempermudah pengerjaan suatu pekerjaan. Syamsuddin dan Damaianti (2006: 14) mengatakan bahawa metode penelitian merupakan cara pemecahan masalah penelitian yang dilaksanakan secara terencana dan cermat dengan maksud mendapatkan fakta dan simpulan agar dapat memahami, menjelaskan, meramalkan, dan mengendalikan keadaan.

Metode deskriptif digunakan tidak terbatas hanya pada pengumpulan dan penyusunan data, tetapi meliputi analisis dan interpretasi tentang arti data itu. Dalam hal ini, metode deskriptif analisis berarti bukan hanya melakukan deskripsi murni, melainkan juga menetapkan arti, dan menarik kesimpulan atau impilkasi. Dengan demikian, metode ini berusaha pula mendeskripsikan fakta secara logis. Melalui metode ini, pendeskripsian data dilakukan dengan cara menunjukkan fakta-fakta yang berhubungan dengan struktur cerita, dilanjutkan dengan penganalisisan fakta-fakta data dan dilengkapi dengan pendeskripsian fungsi dan nilai-nilai karakter yang terdapat dalam dore yang diteliti. Penelitian yang dilakukan adalah penelitian folklor, yaitu penelitian lapangan. Peneliti sendiri berperan sebagai instrumen utama mendapatkan berbagai informasi dan data yang diperlukan dari beberapa orang informan. Untuk mendapatkan data yang lebih lengkap, peneliti melakukan berbagai teknik, baik teknik langsung maupun teknik tidak langsung.

Menurut Danandjaja (2007: 13) bahwa pengumpulan atau pengiventarisan folklor dapat dilakukan dengan dua cara, yaitu; (1) mengumpulkan semua judul karangan (buku dan artikel), yang pernah ditulis orang mengenai Foklore Indonesia; dan (2) mengumpulkan bahan-bahan folklor dari tutur kata orang-orang anggota kelompok yang mempunyai folklor dan hasilnya kemudian langsung diterbitkan atau diarsipkan. Tujuan dari teknik ini adalah untuk melengkapi penelitian. Teknik langsung yang peneliti gunakan untuk mendapatkan data-data yang diperlukan berhubungan dengan dore di Kubu Tuntuangan.

Adapun teknik yang dilakukan adalah: 1) teknik rekaman dan pencatatan, digunakan untuk mendapatkan data utama penelitian berupa cerita yang berkembang di masyarakat dari informan yang dianggap tahu tentang cerita rakyat daerahnya. Teknik pencatatan bisa dipergunakan untuk menstranskripsikan hasil rekaman menjadi bahan tertulis dan mencatat berbagai aspek yang berkaitan dengan suasana penceritaan dan informasi-informasi lain yang dipandang perlu selama melakukan wawancara dan pengamatan. 2) teknik pengamatan (observasi), dilakukan untuk melihat dan mengamati geografis, pola hidup dan sosial budaya yang ada pada masyarakat Kubu Tuntuangan. 3) teknik wawancara, dilakukan terhadap pencerita maupun kepada pemuka masyarakat yangdianggap patut memberikan keterangan mengenai tradisi atau kebiasaan masyarakat setempat. Dalam wawancara ada dua tahap penting.

Tahap pertama 'wawancara bebas' (free interview/ nondirected interview) yang memberi ikebebasan seluas-luasnya kepada informan untuk berbicara.Tahap kedua 'wawancara terarah' (structured/directed interview), yakni mengajukan pertanyaan yang sudah disusun sebelumnya untuk memperoleh gambaran yang utuh dan mendalam (indepth-interview). Konteks Penuturan Data utama penelitian Foklore dore diambil berdasarkan konteks penuturan para informan melalui teknik perekaman.

Data Perkataan Nilai Pendidikan Karakter dalam Permainan Dore di Jorong Kubu Tuntungan 


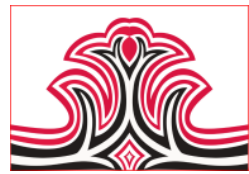

Kenagarian Batipuah. Kecamatan Batipuah Baruah Kab. Tanah Datar.

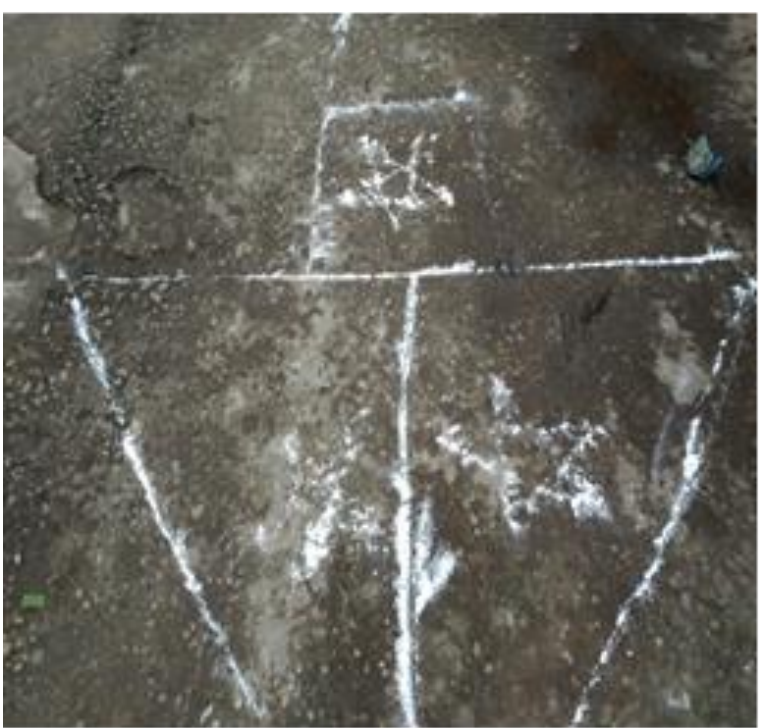

Gambar 2. Replika Denah Foklore Dore Rok Diambil di Kubu Tuntuangan. Batipuah Baruah. 24 Agustus 2020 (Sari, 2020).

\section{HASIL DAN PEMBAHASAN \\ 1.Hasil}

Disini akan di terangkan bentuk perkataan, maksud nilai yang terkadung dalam berkataan serta nilai karakter yang terkadung pada perkataan saat akan meragakan Foklore Dore. (1).Jam ampek sajolah Pak, (Pukul empat saja ya pak,). Perkataan seorang anak laki-laki dalam memutuskan jadwal permaian dore, bahwa permainan dimulai sesudah shalat Asar. (Demoktaris, Peduli). (2) Sasudah sumbayang asar ya pak. (sesudah shalat asar). Melaksanakan perintah Tuhan sesuai dengan agama yang dianut Beriman dan bertaqwa. (3) Dari sikolah masuaknyo, kasinan madoknyo (Ari sini masuknya, kesana menghadapnya) Seorang pemain perempuan mengatur cara membuat Dore. (4) Tungguan wak dulu (Tunggu saya) Permohonan dari penutur kepada para pemain dore agar bersabar menunggu nya sebentar karena dia masih menolong orang tuanya (Berkata apa adanya Jujur) Jan barabuik lo (Jangan berebutan pula) Perkataan seorang opemain laku laki kepada teman prempuannya yang berebut mengambil batu dore Berbuat atas dasar kebenaran Jujur. (5). Jo iko si lah yo (Dengan ini saja ya)Perkataan seorang teman perempuan kepada teman perempuannya yang lain untuk bersedia memakai batu dore dia. Suka menolong dan Peduli. (6) Ndak si Putri, doh Si Tia l(Tidak si Putri tetapi si Tia lagi). Perkataan seorang anak laki-laki kepada teman prempuannya yang keliru mengikuti giliran permainan dalam melempat batu dore Menaati peraturan Peduli. (7) Ndeeh dapek bintang lo ciek kanti wak Hore,
Gorga : Jurnal Seni Rupa

Volume 10 Nomor 01 Januari-Juni 2021

p-ISSN: 2301-5942 | e-ISSN: 2580-2380

(mendapat bintang pula satu lagi teman kita) Perkataan rasa gembira seorang teman kepada teman nya yang memperoleh bintang dalam bermain dore. Berkata apa adanya dan Jujur. (8) Ma lo bantuak itu (Kok seperti itu) Pernyataan seseorang kepada temennya saat bermain dore waktu temannya salah cara melempar batu Dore untuk mendapatkan bintang. Berkata membela kebenaran dan Jujur. (9)Oi Ta. Tolonglah kuampuan batu tu ha (Ta, tolong kumpulkan batu itu ya). Seorang teman laki-laki yang memimpin permainan dore mwenyuruh teman perempuannya Ita mengumpulkan nbatu dore dan meletakkannya pada tempat semula . disiplin dan Tangguh.

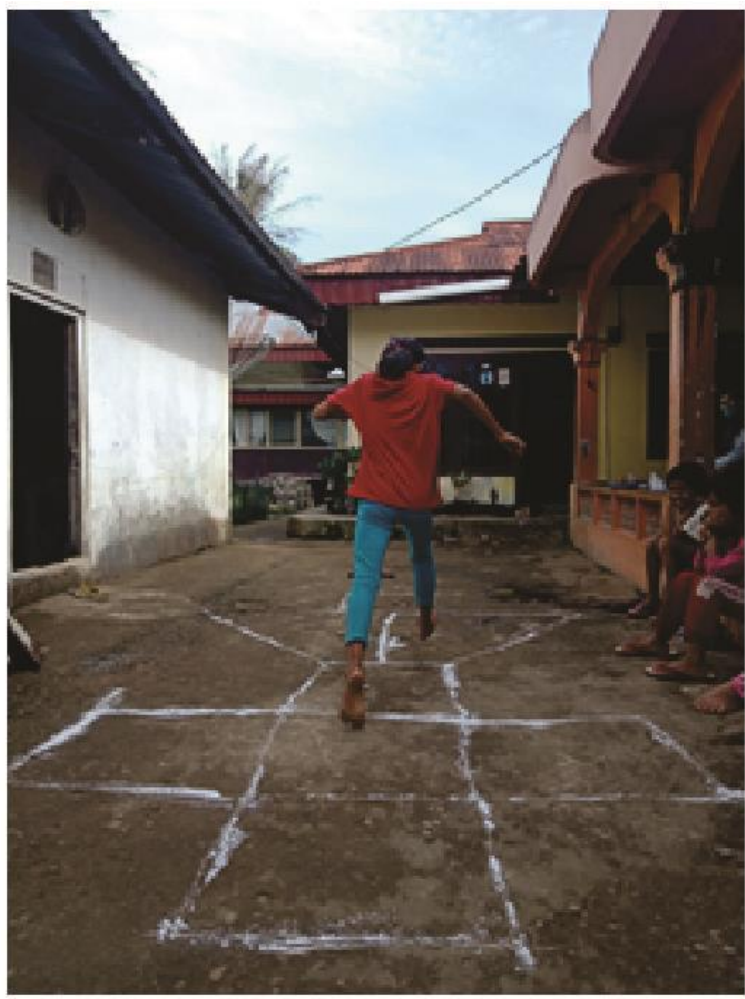

Gambar 3. Peraga Foklore Dore Diambi di Kubu Tuntuangan. Batipuah Baruah. 24 Agustus 2020 (Sari, 2020)

Kesimpulan dari penjabaran di atas yaitu: Data Perkataan Nilai Pendidikan Karakter dalam Permainan Dore di Jorong Kubu Tuntungan Kenagarian Batipuah. Kecamatan Batipuah Baruah Kab. Tanah Datar Berdasarkan tabulasi data di atas dapat dideskripsikan bahawa berdasarkan dokumentasi data perkataan para pemain dore saat melakukan persiapan permaianan, selama melaksanakan permaianan, dan saat menyelesaikan permaianan ditemukan perkataan yang memiliki nilai pendidikan karakter yang sangat dominan. Perkataan tersebut besala dari tuturan para pemai yang berbentuk tuturan langsung atau dialog. Perkataan yang mengandung nilai pendidikan karakter tersebut mengandung nilai 
Gorga : Jurnal Seni Rupa

Volume 10 Nomor 01 Januari-Juni 2021

p-ISSN: 2301-5942 | e-ISSN: 2580-2380

karakter Peduli, bertaqwa kepada tuhan, jujur dan tangguh. Nilai pendidikan karakter yang dominan muncul adalah nilai karakter jujur.

Berikutnya peneliti menemukan data perbuatan nilai pendidikan karakter dalam permainan dore di Jorong Kubu Tuntungan Kenagarian Batipuah. Kecamatan Batipuah Baruah Kab. Tanah Datar. Bentuk Perbuatan yang Dilakukan Saat Bermain Dore yaitu:

(1) dua orang dengan spontan membuat peta dore tanpa disururuh atau dikomandokan (Gotong royong Peduli). (2)Seseorang teman perempuan menyingkirkan batu batu kecil yang berserakan di halaman tempat pet adore di buat saat temannya membuat peta dore (Suka menolong dan Peduli). (3) Seorang teman laki laki memimpin penentuan nomor urut bermain Dan teman teman yang lain mengikuti nya (Menaati perintah sesuai dengan tugas dan kewajiban dan Peduli) (4) Sesorang yang membuat peta dore mengganti. (5) posisi denah yang akan dibuat sesuai dengan yang dianjurkan oleh seorang teman perempuannya. Kemudian Dua orang teman perempuan menunggu seorang temannya di depan rumah yang sedang menyelesaikan pekerjaannya membantu orang tuanya (Sikap kekeluargaan dan Peduli). (6) Dua orang teman perempuan diam dan mengalah setelah diperingatkan oleh seorang teman perempuannya (Menaati perintah dan Peduli). (7) Seorang temen perempuan yang tidak memiliki batu dore menerima tawaran dari pemenya untuk memekai batu dorenya,(Sikap kekeluargaan dan Peduli). (8)Tia (seorang pemain dore perempuan) mengalah dan mundur setelah diperingatkan oleh teman laki-lakinya bahwa bukan gilirannya tetapi giliran si Putri (Loyal dengan menaati perintah dan Peduli). (9)Bebrapa teman bergembira melihat sorang temannya mearih bintang lagi (bintang yang ketiga) dalam bermain dore (Bersikap kekeluargaan Peduli). (10). Seorang teman menerima dengan baik kesalahannya melempar batu dore saat akan meraih bintang sehingga dia didiskualifikasi untuk satu putaran permainan (Lapang dada dan Jujur). (10). Seorang pemain dore memberikan sebagaian makanan ringan yang dimakannya sat duduk berdua berdekatan menunggu giliran bermain dore dan temannya menerima dengan senang hati (Sikap kekeluargaan dan Peduli). (11) Seorang teman mengumpulkan batu dore dan meletakkannya ke tempat semula setelah disuruh oleh teman laki-lakinya (Menaaati perintah dan Peduli).

Berdasarkan tabulasi data tetentang data perbuatan nilai pendidikan karakter dalam permainan dore di Jorong Kubu Tuntungan Kenagarian Batipuah.
Kecamatan Batipuah Baruah Kab. Tanah Datar di atas dapat dideskripsikan bahwa ditemukan perbuatan para pemain dore saat melakukan persiapan permaianan, selama melaksanakan permaianan, dan saat menyelesaikan permaianan yang memiliki nilai pendidikan karakter. Perbuatan tersebut berasal dari ttindakan para pemain. Perbuatan yang mengandung nilai pendidikan karakter tersebut tergolong kepada nilai karakter peduli, dan jujur. Nilai pendidikan karakter yang dominan muncul adalah nilai karakter peduli.

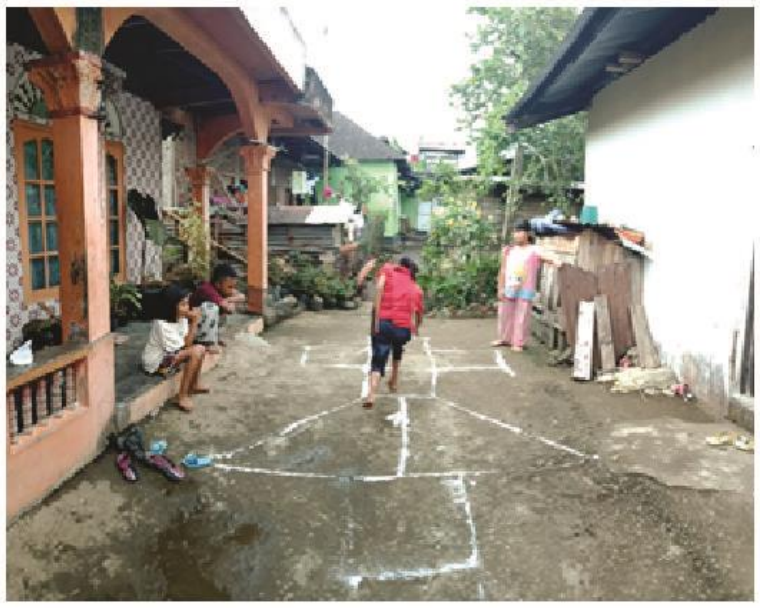

Gambar 4. Peraga Foklore Dore Diambi di Kubu Tuntuangan. Batipuah Baruah. 24 Agustus 2020 (Sari, 2020).

Hal yang peneliti lihat pada Foklore Dore selanjutnya yaitu indikator nilai karakter yang terdapat pada bentuk perkataan (tutur) saat anak-anak memperagakan Foklore Dore tersebut. (1) Jam ampek sajolah Pak,Pukul empat saja ya pak, Perkataan seorang anak laki-laki dalam memutuskan jadwal permaian dore, bahwa permainan dimulai sesudah shalat Asar (Demoktaris,Peduli) (2). Sasudah sumbayang asar ya pak sesudah shalat asar Melaksanakan perintah Tuhan sesuai dengan agama yang dianut (Beriman dan bertaqwa). (3). Dari sikolah masuaknyo, kasinan madoknyo dari sini masuknya, kesana menghadapnya Seorang pemain perempuan mengatur cara membuat Dore. (4) Tungguan wak dulu artinya Tunggu saya Permohonan dari penutur kepada para pemain dore agar bersabar menunggu nya sebentar karena dia masih menolong orang tuanya (Berkata apa adanya , Jujur). (5) Jan barabuik lo bermakna Jangan berebutan pula. Perkataan seorang opemain laku laki kepada teman prempuannya yang berebut mengambil batu dore (Berbuat atas dasar kebenaran, Jujur). (6) Jo iko si lah yo bermakna Dengan ini saja ya. Perkataan seorang teman perempuan kepada teman perempuannya yang lain untuk bersedia memakai batu dore dia (Suka menolong dan Peduli). (7) Ndak si Putri, doh Si Tia lai 


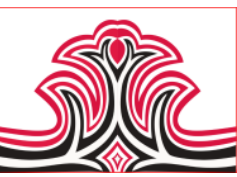

bermakna Tidak si Putri tetapi si Tia lagi Perkataan seorang anak laki-laki kepada teman prempuannya yang keliru mengikuti giliran permainan dalam melempat batu dore (Menaati peraturan dan Peduli) (8) Ndeeh dapek bintang lo ciek kanti wak artinya Hore, mendapat bintang pula satu lagi teman kita. Perkataan rasa gembira seorang teman kepada teman nya yang memperoleh bintang dalam bermain dore. (Berkata apa adanya dan Jujur). (9) Ma lo bantuak itu. Kok seperti itu. Pernyataan seseorang kepada temennya saat bermain dore waktu temannya salah cara melempar batu Dore untuk mendapatkan bintang. (Berkata membela kebenaran dan Jujur). (10) Oi Ta. Tolonglah kuampuan batu tu ha artimya Ta, tolong kumpulkan batu itu ya. Seorang teman laki-laki yang memimpin permainan dore mwenyuruh teman perempuannya Ita mengumpulkan batu dore dan meletakkannya pada tempat semula. (disiplin tangguh).

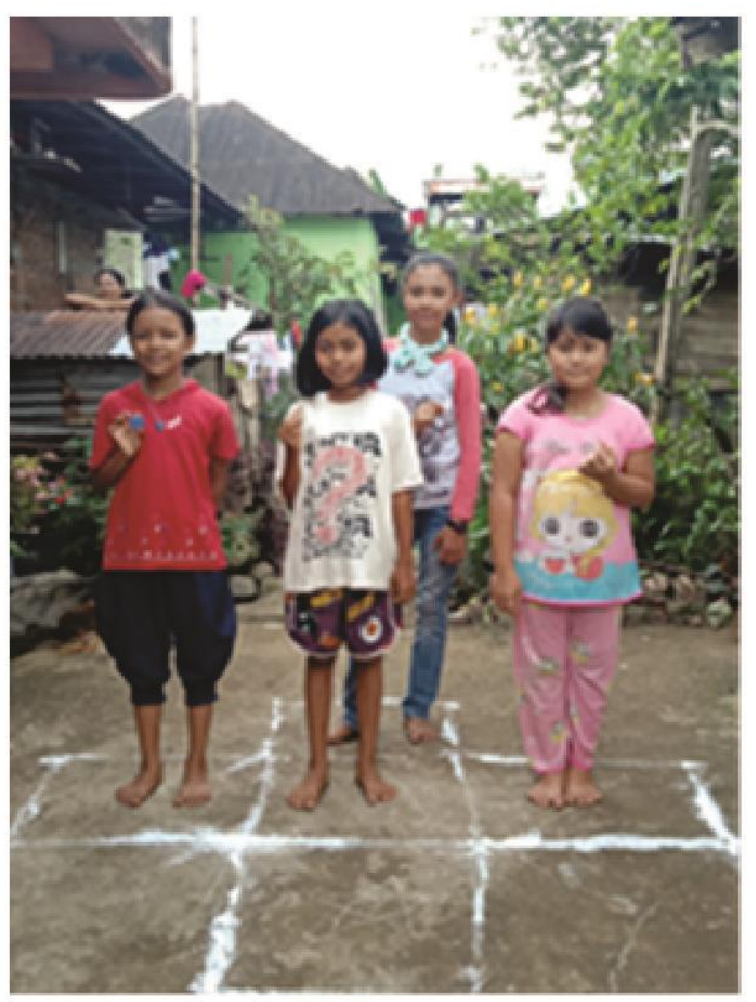

Gambar 5. Pelaku Foklore Dore Diambil di Kubu Tuntuangan. Batipuah Baruah. 24 Agustus 2020 (Sari, 2020).

\section{Pembahasan}

Data Perbuatan Nilai Pendidikan Karakter dalam Permainan Dore di Jorong Kubu Tuntungan Kenagarian gBatipuah.an Kecamatan Batipuah Baruah Kab. Tanah Datar. Berikut memuat keterangan data bentuk perbuatan yang di lakukan saat bermain Dore, berikut di lanjutkan penjelasan indikator serta nilai pendikan karater sesuai data bentuk perbuatan. (1). dua orang dengan spontan membuat peta dore tanpa disururuh atau dikomandokan dengan nilai karakter
Gorga : Jurnal Seni Rupa

Volume 10 Nomor 01 Januari-Juni 2021

p-ISSN: 2301-5942 | e-ISSN: 2580-2380

Gotong royong. (2) Nilai Peduli yaitu Seseorang teman perempuan menyingkirkan batu batu kecil yang berserakan di halaman tempat peta dore di buat saat temannya membuat peta dore. Nilai karakter yaitu Suka menolong dan Peduli. (3) Seorang teman laki laki memimpin penentuan nomor urut bermain Dan teman teman yang lain mengikuti nya Menaati perintah sesuai dengan tugas dan kewajiban. Nilai karakter yang muncul yaitu Peduli. (4) Sesorang yang membuat peta dore mengganti posisi denah yang akan dibuat sesuai dengan yang dianjurkan oleh seorang teman perempuan. Dua orang teman perempuan menunggu seorang temannya di depan rumah yang sedang menyelesaikan pekerjaannya membantu orang tuanya. Nilai Karakter yang muncul yaitu Sikap kekeluargaan dan Peduli. (5) Dua orang teman perempuan diam dan mengalah setelah diperingatkan oleh seorang teman perempuannya. Nilai Karakter yang muncul yaitu Menaati perintah dan Peduli.

(6) Seorang temen perempuan yang tidak memiliki batu dore menerima tawaran dari pemenya untuk memekai batu dorenya. Nilai karakter yang muncul yaitu Sikap kekeluargaan dan Peduli. (7) Tia (seorang pemain dore perempuan) mengalah dan mundur setelah diperingatkan oleh teman laki-lakinya bahwa bukan gilirannya tetapi giliran si Putri. Nilai karakter yang muncul yaitu Loyal dengan menaati perintah dan Peduli. (8) Bebrapa teman bergembira melihat sorang temannya mearih bintang lagi (bintang yang ketiga) dalam bermain dore. Bersikap kekeluargaan dan peduli. (9) Seorang teman menerima dengan baik kesalahannya melempar batu dore saat akan meraih bintang sehingga dia didiskualifikasi untuk satu putaran permainan. Nilai karakter yang muncul yaitu Lapang dada dan Jujur. (10) Seorang pemain dore memberikan sebagaian makanan ringan yang dimakannya sat duduk berdua berdekatan menunggu giliran bermain dore dan temannya menerima dengan senang hati. Nilai Karakter yang muncul yaitu Sikap kekeluargaan dan Peduli. (11) Seorang teman mengumpulkan batu dore dan meletakkannya ke tempat semula setelah disuruh oleh teman laki-lakinya. Nilai karakter yang muncul yaitu Menaaati perinta dan Peduli. Data Tingkah Laku Nilai Pendidikan Karakter dalam Permainan Dore di Jorong Kubu Tuntungan Kenagarian Batipuah. Kecamatan Batipuah Baruah Kab. Tanah Datar.

Bentuk tingkah laku dalam permaian dore serta indikator Nilai pendidikan karakter yaitu; (a) Saat persiapan bermain dore akan dimulai keliatan antusias keliatan para pemain dengan suasana kekeluargaan (Sikap kekeluargaan dan Peduli) (b). Ditemukan seorang pemain perempuan yang masih malu-malu 


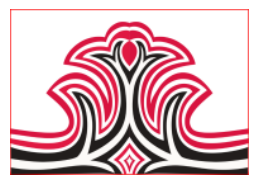

sehingga dia menurut semua aturan bermain sesuai yang ditentuakan Memenuhi (kewajiban dan jujur). (c) Seorang pemain perempuan sangat gembira ketika mendapat giliran bermain maka dia bernyanyi -nyayi dan tertawa juga saat dia menyelesaikan permaian dorenya (Berkata apa adanya dan Jujur). (d). Seorang teman prempuannya saat isttirahat menunggu giliran pulang ke rumahnya yang tidak jauh dari tempat bermain dore, seketika kembali dengan membawa makanan ringan sejenis kripik. Teman-teman yang lain dating menyerbu dengan rasa gembira disertai tawa dan senda. Mereka dapat bagian sedikit seorang. Ada sesorang temen yang tidak kebagian maka dia minta dan diberi oleh temnya yang lain byag sudah terlebih dahulu mendapat bagian. (Sikap kekeluargaan dan Peduli ). (d). Semua anak-anak pemain dore beregembira saat permainan selesai da nada yang berkejar-kejaran sambil tertawa dan berlarian (kekeluargaan).

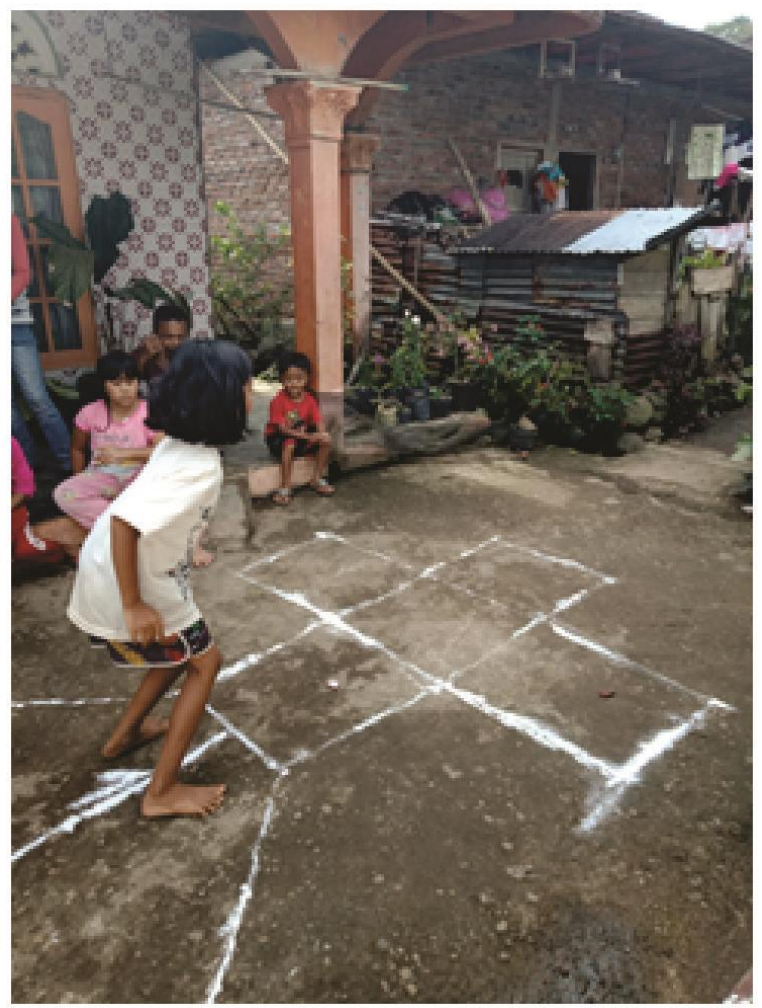

Gambar 6. Pelaku Foklore Dore Diambil di Kubu Tuntuangan. Batipuah Baruah 24 Agustus 2020 (Sari, 2020).

Data Aktivitas Nilai Pendidikan Karakter dalam Permainan Dore di Jorong Kubu Tuntungan Kenagarian Batipuah. Kecamatan Batipuah Baruah Kab. Tanah Datar Bentuk aktivitas dalam permaian dore, Makna dan Indikator Nilai pendidikan karakter, yaitu: 1. Sebelum bermain dore dimulai para pemain dore bekerja secara sukarela berbagi tugas, yaitu: (a) Satu orang menyapu halaman tempat membuat denah
Gorga : Jurnal Seni Rupa

Volume 10 Nomor 01 Januari-Juni 2021

p-ISSN: 2301-5942 | e-ISSN: 2580-2380

dore, (b) Dua orang membuat peta dore, (c)Satu orang menyediakan batu dore, (d)Tiga orang duduk berbarengan memegang-megang batu dore yang dibagikan temannya, (e) Satu orang teman laki-laki nya memperhatikan dan membetulkan teman perempuannya membuat pet dore.(Gotong royong dan peduli). 2. Setelah peta dore selesai dibuat, seorang teman laki-laki memimpin pembagian urutan bermain dor Mampu memecahkan masalah dan Cerdas. 3. Saat permaian dore dilaksanakan para pemain yang menunggu giliran bermain duduk berderet di pelataran rumah. Seorang pemain laki-laki yang biasanya dituakan dalam permaian dore itu berdiri dekat pet adore memperhatikan setiap temannya bermain (disiplin dan Tangguh). 4. Setelah permainan dore selesai dilaksanakan para pemain kembali tanpa dikomandokan menyimpan alat-alat permain ketempat semula. Dan yang tidak bertugas bergembira berlarian dan tertwa sambil bernyanyi nnyanyi (terbukadan Cerdas).

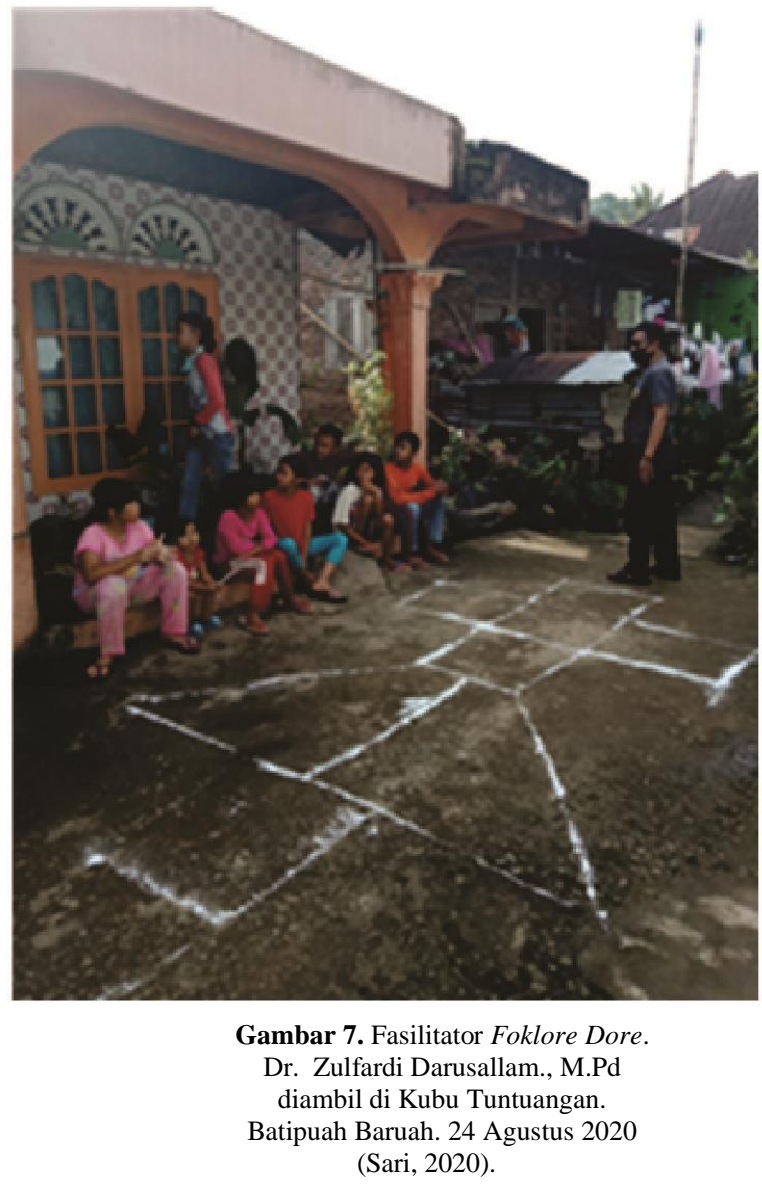

\section{1). Tutur Foklore Dore}

Sebelum di mulai, anak-anak bersorak sorai sambil berhitung kemudian menyebutkan.... Timbangtimbang- Mamimbang samo barek, maukua samo panjang (menimbang sama berat, mengukur sama panjang). Panjang di ulai, singkek di bilai (panjang 


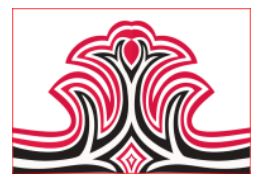

dan pendek harus di bagi sama rata) Balasuik...balasuik,,,(hompimpa). Mari kito balasuik,,,,Balasuik,,,balasuik,,, $\quad$ Ciek,,duo,,,tigo,,, (satu,,,dua,,tiga,,). Nan kanai angko satu inyo nan mulo.... (yang dapat angka 1 silakan duluan) (permulaan folklore di mulai dengan menentukan siapa yang terpilih nomor 1, dengan melempar batu ke luar kotak). Mauntai kato-kato, mauntai lambeklambek. (jika berkata-kata, harus di perhatikan). Hati ketek acok taibo, pabilo anak indak manjawek. (perasaan orang tua sering iba apabila anak-anak mereka tidak patuh). (ketika sampai ke kotak 4) Hai...hai...hai.. (bersorak) (hai---hai-haii). Iko cabuak basuahlah kaki (seringlah mengkoreksi diri ). Kok ado nan indak samparono, mari kito peloki (jika ada yang keliru, mari sama-sama kita perbaiki) (ketika sampai ke kotak 6). Jikok ado galeh tangah rumah, baok ka dapua pambaok saka. (jika kita mempunyai reseki yang berlebih, suka rela lah untuk berbagi). Jikok ado tingkah nan salah, suok ajari adaik nan bana. (jika kita pernah berbuat salah pada sesame, mulailah dengan minta maaf dan saling mengajari sesuai nilai-nilai norma) (kotak terakhir).

\section{KESIMPULAN DAN SARAN}

\section{Kesimpulan}

Berdasarkan tabulasi data aktivitas yang mengandung nilai pendidikan karakter dalam permainan dore di Jorong Kubu Tuntungan Kenagarian Batipuah. Kecamatan Batipuah Baruah Kab. Tanah Datar di atas dapat dideskripsikan bahwa ditemukan tinaktivitas para pemain dore saat melakukan persiapan permaianan, selama melaksanakan permaianan, dan saat menyelesaikan permaianan yang memiliki nilai pendidikan karakter. Aktivitas tersebut berasal dari tindakan para pemain. Aktivitas yang mengandung nilai pendidikan karakter tersebut tergolong kepada nilai karakter peduli, cerdas dan tangguh. Nilai pendidikan karakter yang dominan muncul adalah nilai karakter cerdas.

Berdasarkan deskripsi hasil tabulasi data nilai pendidikan karakter dalam permainan dore di Jorong Kubu Tuntungan Kenagarian Batipuah. Kecamatan Batipuah Baruah Kab. Tanah Datar dapat dijelaskan bahwa permaianan dore merupakan sebuah permaian tradisi anak nagari di kabupaten Tanah Datar pada umumnya dan di jorong Kubu Tuntungan pada khususnya merupakan sarana pendidikan non formal yang di dalamnya sarat dengan nilai pendidikan karkater. Dalam permaian tersebut secara tak langsung anak-anak di njorng kubu Tuntungan menerima pembelajaran karakter. Berdasarkan hasil penelitian yang dilakukan ada tiga nilai pendidikan karakter yang
Gorga : Jurnal Seni Rupa

Volume 10 Nomor 01 Januari-Juni 2021

p-ISSN: 2301-5942 | e-ISSN: 2580-2380

menonjol dalam permaiann dore tersebut, yaitu 1. Nilai pendidikan karakter jujur, 2 Nilai pendidikan karakter Peduli dan 3 nilai pendidikan karakter cerdas. Ketiga nilai pendidkan karakter tersebut muncul dalam diri para pemain secara tak langsung, tanpa dikomando dan tidak melalui indroktinasi. Mereka melakukan perbuatan, aktivitas dan pembicaraan sesuai dengan kondisi keseharian mereka dan kondisi permaian yang mereka lakukan.

\section{Saran}

Ada beberapa saran yang dapat dijadikan bahan masukan yang bermanfaat bagi pihak pihak yang bersangkutan adalah sebagai berikut :

1). Peran tenaga pendidik sangat penting dalam mengedukasi siswa dalm menerpkan nilai karakter pada setiap jenjang pendidikan.

2). Dengan adanya penelitin ini di harapkan proses pembelajaran guna penerapan nilai karakter tidak hanya pada proses pembelajaran formal di bangku sekolah, namun bisa juga melalui pembelajaran di lapangan dengan melihat media-media pendukung yang terdapat pada masyarakat.

\section{DAFTAR RUJUKAN}

. (2012). Petunjuk Pelaksanaan

Pembelajaran Karakter Cerdas Format

Kelompok. Padang: Universitas Negeri Padang.

Adisusilo, Sutarjo. (2012). Pembelajaran NilaiKarakter. Jakrata: Raja Grafindo Persada.

Arikunto, Suharsimi. (2006). Prosedur Penelitian Suatu Pendekatan Praktik. Jakarta: Rineka Cipta.

Danandjaja, James. (2007). Folkloree Indonesia. Jakarta: Grafiti

Iskandarwassid, Dadang. (2009). Sunendar, Strategi Pembelajaran Bahasa: Bandung. PT Remaja Rosdakarya.

Moleong, J. Lexy. (2009). Metode Penelitian Kualitatif. Bandung: PT. Remaja Rosdakaya.

Nazir, M. (2003). Metode Penelitian. Jakarta: Ghalia Indonesia.

Prayitno \& Afriva Khaidir. (2011). Model Pendidikan Karakter Cerdas. Padang: UNP Press.

Sari, D. P. (2020). "Foklore Dore". Hasil Dokumentasi Pribadi: 24 Agustus 2020, Batipuah Baruah.

Syamsuddin, A.R. \& Damaianti, Vismaia S (2006). Metode Penelitian Pendidikan Bahasa. Bandung: PT Remaja Rosdakarya.

Suwardi, Endraswara. (2013). Fokloree Nusantara Hakikat, Bentuk, dan Fungsi. Yogyakarta: Penerbit Ombak.

Setiadi, E. M. (2006). Ilmu Sosial dan Budaya Dasar. Jakarta: Kencana Prenanda Media Group. 